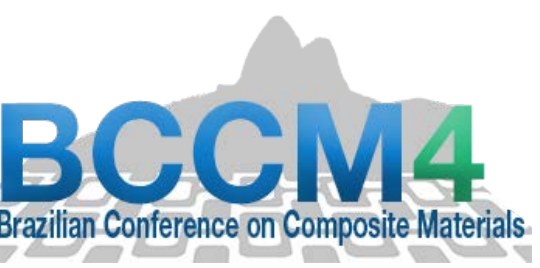

\title{
EFFECT OF CHEMICAL TREATMENTS ON THERMAL PROPERTIES OF IMPERATA BRASILIENSIS GRASS TO REINFORCE COMPOSITES WITH POLYMERIC MATRIX
}

\author{
Thiago de S. Dias ${ }^{(1)}, \underline{\text { Kelly C. C. de C. Benini }}{ }^{(2)}$ and Maria O. H. Cioffi ${ }^{(2)}$ \\ (1) Department of Materials and Technology, School of Engineering of Guaratinguetá-UNESP, \\ Brazil.
}

https://doi.org/10.21452/bccm4.2018.10.11

\begin{abstract}
The development of new materials has been occurring in order to obtain solutions environmentally more effective. In this context, natural fibers have been used as reinforcement in polymer matrix composites, since they present low density and biodegradability. In the present work Imperata brasiliensis grass was chemically treated by acetosolv treatment using a solution of acetic acid $93 \mathrm{wt} \%$ at $110{ }^{\circ} \mathrm{C}$, under reflux, using hydrochloric acid solution 0.3 wt $\%$ as catalyst, and bleached with a $1: 1$ solution of $\mathrm{NaOH} 4 \%(\mathrm{w} / \mathrm{v})$ and $\mathrm{H}_{2} \mathrm{O}_{2} 30 \%(\mathrm{v} / \mathrm{v})$ at 70 ${ }^{\circ} \mathrm{C}$ for $3 \mathrm{~h}$. Untreated and treated fibers were characterized by thermogravimetric analysis (TGA/DTG) and scanning electron microscopy (SEM) and also the color changes after each chemical treatment were considered. According to the results of TGA, the thermal stability of the fiber has increased, comparing untreated and bleached fibers. TGA results also showed the removal of some peaks which is related to the removal of amorphous constituents, a consequence that was also observed trough color analysis. Furthermore, SEM micrographs indicates a defibrillation of fiber after each chemical treatment, a result that can upgrade the anchorage between fiber and matrix and increase subsequent properties of the composite.
\end{abstract}

Key-words: Natural fibers. Composites. Imperata brasiliensis. Acetosolv. Bleaching

\section{INTRODUCTION}

The current development in materials area is seeking to assemble better properties to environmental issues with the view to perform material that are less harmful to the environment [1]. In this sense, natural fibers that were just used for traditional applications as in handicraft for example has been studied to be applied as reinforcement on composites and biocomposites with polymeric matrices [2,3]. Natural fibers show characteristics like low density, biodegradability, recyclable and require low energy consumption in production. On the other hand, they have been used as an alternative solution to the ever-depleting non-renewable materials and oil products like plastics in general [4,5]. Many industries such as automotive 
industry is already using this idea in its products, since natural fiber polymer composites are being used in internal and external non-structural applications [6,7].

Natural fibers are mainly composed of cellulose, hemicellulose and lignin. These useful components are present inside plants' cell wall that is formed by fibrils compound of microfibrils. Nonetheless, other components as waxes, ash and extractives are also present in less quantity [8]. However, the union of natural fibers and polymeric matrices is hampered by hydrophilic character of natural fibers. This characteristic can be attributed to hydroxyl groups intra and intermolecular of fibers that combine to water molecules of atmosphere. The adhesion between natural fiber and polymer and characteristics like water absorption and low thermal stability of fibers have been aiming to study over last years [9].

For this reason, physical, thermal and chemical treatments were developed for fibers. Chemical treatments like acetylation, benzoylation, peroxide, etc., are extensively used in view of distending the crystalline region, eliminating the hydroxyl groups and removing impurities from the surfaces [10]. Furthermore, the most interesting component for composites is cellulose because its crystalline portion, which grant good mechanical properties in composites [11]. Chemical treatments as organosolv can also result in a fractionation of fiber components ant this one can be highlighted as a promising method because it uses an organic solvent [12]. Besides that, bleaching treatment is also carried out to remove the residual amorphous components obtaining a considerable white fiber, where cellulose is mostly present [13]. In this study, organosolv pulping with acetic acid and bleaching with sodium hydroxide and hydrogen peroxide were carried out for Imperata brasiliensis grass, an invasive native species of grass, with the aim of improving its thermal properties and surface aspect for later uses as a reinforcement to polymeric composites materials.

\section{MATERIALS AND METHODS \\ 2.1. Raw Materials}

Imperata brasiliensis fibers were collected in Guaratingueta's countryside. The entire grass (root, stem and leaf) was cut into slices with random lengths using a Garthen GP-1500 AB machine. Subsequently, these grasses were milled using a Knife Mill Tecnal TE-650 and fibers separated through a sieve 8 mesh to obtain the powder that was used in this study. The fiber powder was dried in an oven at $60{ }^{\circ} \mathrm{C}$ during $24 \mathrm{~h}$.

\subsection{Acetosolv treatment}

With the milled and dry fiber, the chemical treatment of acetosolv pulping was first carried out with acetic acid solution $93 \mathrm{wt} \%$ at $110{ }^{\circ} \mathrm{C}$ under reflux, using hydrochloric acid solution $0.3 \mathrm{wt} \%$ as catalyst, performing with a fiber/solvent ratio of 1:10 (w/v). The system stayed under stirring for $180 \mathrm{~min}$. and then the solid fraction (that was composed mainly by cellulose) was washed once with acetic acid to avoid lignin re-condensation on the fiber. Finally, the acetosolv pulp was washed with distilled water until reached a neutral $\mathrm{pH}$ and it was dried at 60 ${ }^{\circ} \mathrm{C}$ for $24 \mathrm{~h}$ to obtain the treated fiber.

\subsection{Bleaching treatment}

Treated fibers were bleached with a 1:1 solution of $\mathrm{NaOH} 4 \%(\mathrm{w} / \mathrm{v})$ and $\mathrm{H}_{2} \mathrm{O}_{2} 30 \%(\mathrm{v} / \mathrm{v})$ at $70^{\circ} \mathrm{C}$ for 3h. Approximately $15 \mathrm{~g}$ of fibers were added in $900 \mathrm{ml}$ of $\mathrm{NaOH} / \mathrm{H}_{2} \mathrm{O}_{2}$ solution and stirred at $4000 \mathrm{rpm}$. Every hour until complete $3 \mathrm{~h}$ of reaction it was added more $90 \mathrm{ml} 4 \%$ (w/v) $\mathrm{NaOH}$ and $90 \mathrm{ml} \mathrm{30 \%} \mathrm{(v/v)} \mathrm{H}_{2} \mathrm{O}_{2}$. Finally, the solution was washed until achieve neutral $\mathrm{pH}$ and then bleached fiber was also dried at $60^{\circ} \mathrm{C}$ for $24 \mathrm{~h}$. 


\subsection{Thermogravimetric Analysis}

The untreated, treated and bleached fibers were characterized by TGA analysis using a TG/DTG SII Nanotechnology INC thermobalance (model 6200) with a heating rate of $10^{\circ} \mathrm{C}$ $\min ^{1}$, under nitrogen flow, using a temperature range from $25^{\circ} \mathrm{C}$ to $800^{\circ} \mathrm{C}$. The initial degradation temperature was obtained from the first baseline deviation observed, based on ASTM E2550 [14]. Through this analysis, it was also possible to observe the mass losses within the temperature range for each thermal event.

\subsection{Scanning Electron Microscopy (SEM)}

The morphology of the untreated, treated and bleached fibers was analyzed in a Zeiss EVO 17 LS-15 scanning electron microscope with Oxford INCA Energy 250 EDS / EBDS system, operating from 15 to $20 \mathrm{~kW}$ and using secondary electron detector. It was used a self-adhesive carbon double-sided tape, the samples were fixed in a holder and coated with gold.

\section{RESULTS AND DISCUSSIONS}

\subsection{Color analysis}

The images of fibers before (Fig 1a) and after each chemical treatment are presented at Fig. 1. After carrying out acetosolv pulping the fibers became darker, according to Fig 1b. This fact may be justified by removing of hemicellulose from the constituents of the fiber, since hemicellulose which is more easily soluble in the organic solvent. Although lignin can be removed, it may have occurred less intensely because it is composed by a structure that is more complex [15]. The dark brown coloring can be explained by the presence of chromophore groups, molecules or parts of molecules, which excites an electron that emits the photons of the color in question, when these molecules are hit by light. These chromophore groups may be present in hexenuronic acids (hemicellulose), hydrated carbohydrates, extractives, transition metals, but mainly in residual lignin, present in the acetosolv pulp [16].

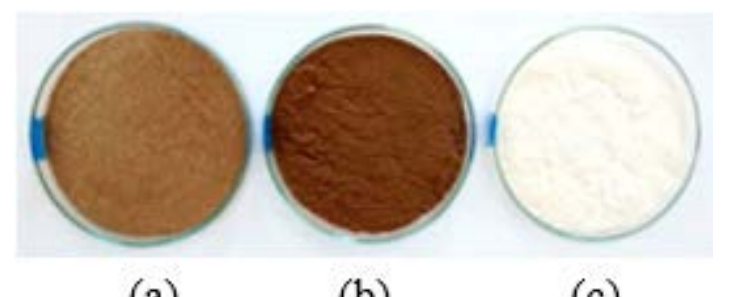

(a)

(b)

(c)

Fig. 1: Color modification on Imperata brasiliensis fibers after acetosolv and bleaching treatments.

After bleaching treatment, the fiber reached significant levels of whiteness (Fig. 1c), due to the removal of amorphous components such as mainly lignin, and metallic ions [17]. Using hydrogen peroxide to bleach the fiber, the hydroperoxide ion that is formed by the dissociation of the peroxide in the alkaline medium is responsible for the discoloration of the fiber, since these ions attack the remaining lignin and cellulose chromophores in the pulp [13].

\subsection{Thermogravimetric analysis}

Thermogravimetric curves of untreated, treated and bleached fibers are presented at Fig. 2. The main thermal parameters obtained from these results can be seen in Table 1. 


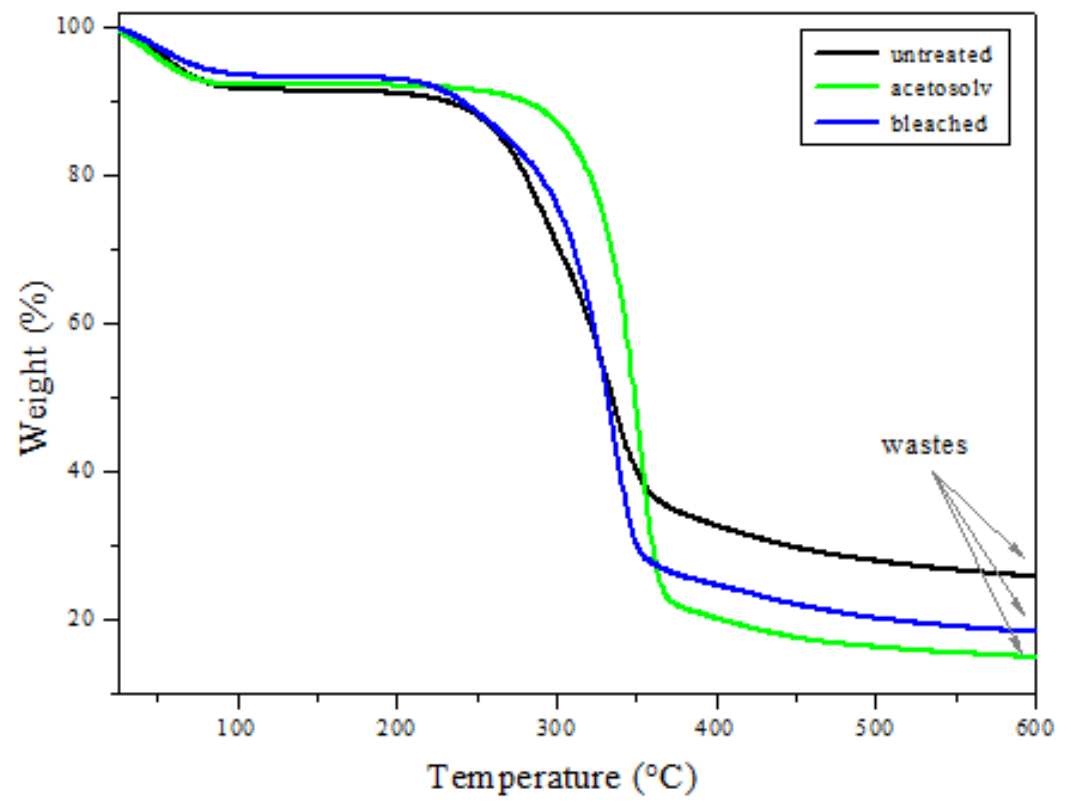

Fig.2: TG curves of untreated, treated and bleached Imperata brasiliensis fibers.

From TGA curves of all fibers it is possible to observe a first weight loss at around $10 \%$ up to $100{ }^{\circ} \mathrm{C}$, referring to the dehydration reactions of the water absorbed by the fiber, very common in analyzes of other lignocellulosic fibers [18]. It is also observed after acetosolv pulping, that the thermal stability of fiber increased from $152{ }^{\circ} \mathrm{C}$ to $168{ }^{\circ} \mathrm{C}$. In the analysis of the curves referring to the bleached fiber it is possible to observe that the thermal stability of the fiber decreased in comparison to acetosolv pulp, going from 168 to $160{ }^{\circ} \mathrm{C}$. Although the thermal stability has decreased from acetosolv to bleaching, removing of the amorphous components can be observed by the high whiteness of the bleached fiber, which can improve the properties of the composites and may expand its using in several performing processes [1]. Regarding to the wastes, in untreated fiber there are approximately $25.8 \%$ at $600{ }^{\circ} \mathrm{C}$ due to carbonaceous residues and some part of non-degraded fiber [19].

In addition, it is possible to observe the degradation stages of the fiber through DTG curves that are shown in Fig.3. Regarding to untreated fibers, three degradation stages are observed, the first one related to water absorbed, the second one at about $300{ }^{\circ} \mathrm{C}$ corresponding to the degradation of the hemicelluloses, and the third one, between 300 and $375{ }^{\circ} \mathrm{C}$, related to the degradation of mainly cellulose [1]. Lignin degradation occurs slowly throughout any thermal event, between approximately 450 and $700{ }^{\circ} \mathrm{C}$. Lignin is formed by aromatic rings and so its structure is more complex comparing to cellulose and hemicellulose [18]. One cannot observe a specific peak related to lignin degradation. However, the fourth stage of degradation in DTG curve (Fig. 3) can be associated to chemical reactions such as the breaking of lignin C-C bonds, releasing of water, $\mathrm{CO}$ and $\mathrm{CO}_{2}$ during heat [20]. 


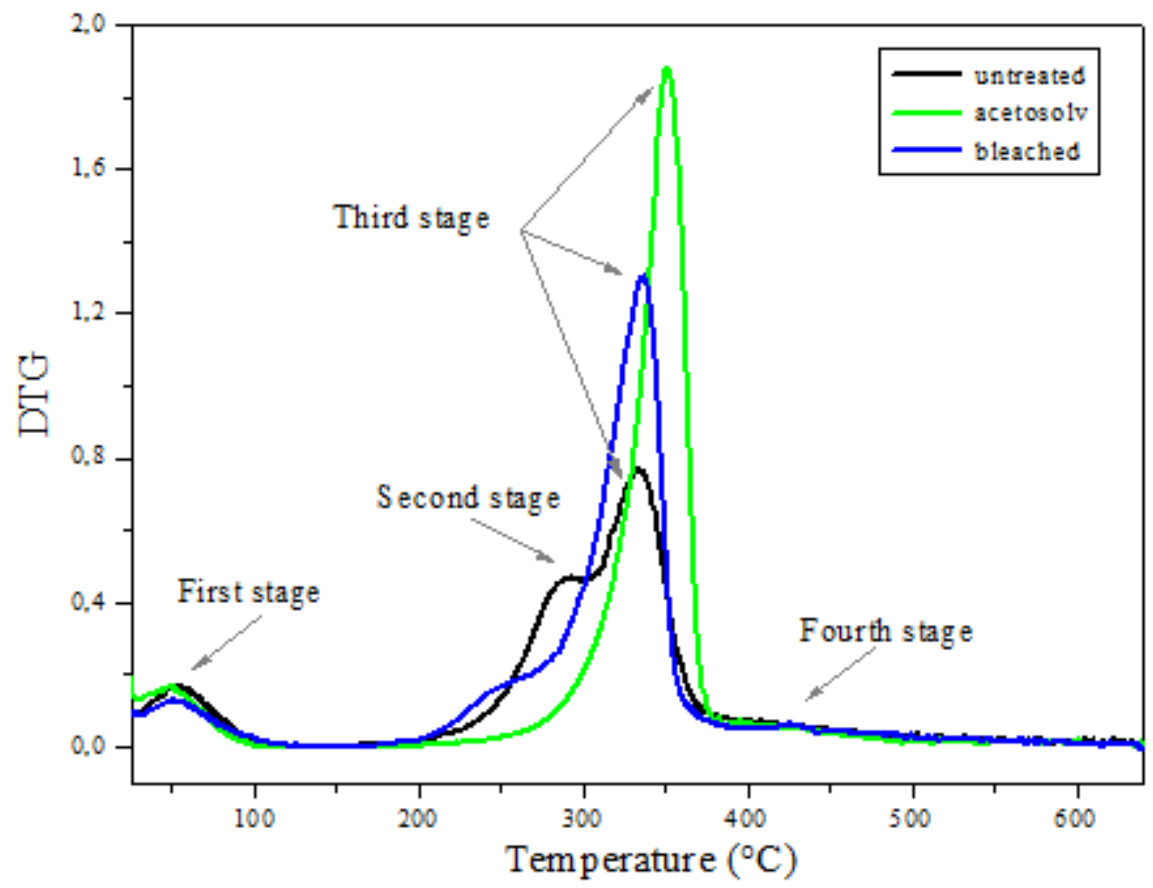

Fig.3: DTG curves of untreated, treated and bleached Imperata brasiliensis fibers. Nitrogen atmosphere $\left(10{ }^{\circ} \mathrm{C} \cdot \mathrm{min}^{-1}\right)$.

Table 1 shows the TG/DTG parameters for all fibers and their degradations stages, which were already reported. According to acetosolv parameters, one cannot see a second stage, which must be associated by removing of hemicellulose of the fibers, as it was also observe by color analysis. Finally, analyzing TG of bleached fiber one can see a peak at about $250^{\circ} \mathrm{C}$, this peak was not expected, since hemicellulose, which is degraded in this temperature range has been probably removed by acetosolv, so this shoulder may possibly be related to a contamination or bleaching residues.

\begin{tabular}{|c|c|c|c|c|c|c|}
\hline Samples & $\begin{array}{c}\text { Degradation } \\
\text { stages }\end{array}$ & $\begin{array}{c}\Delta \mathrm{T} \\
\left({ }^{\circ} \mathrm{C}\right)\end{array}$ & $\begin{array}{l}\mathbf{T}_{\text {peak }} \\
\left({ }^{\circ} \mathrm{C}\right)\end{array}$ & $\begin{array}{c}\mathbf{T}_{\mathbf{i}} \\
\left({ }^{\circ} \mathbf{C}\right)\end{array}$ & $\begin{array}{c}\text { Weight loss } \\
(\%)\end{array}$ & $\begin{array}{l}\text { Residue at } \\
600^{\circ} \mathrm{C}(\%)\end{array}$ \\
\hline \multirow{4}{*}{ Untreated } & $1 s t$ & 25-130 & 54 & \multirow{4}{*}{152} & 8.3 & \multirow{4}{*}{25.8} \\
\hline & 2nd & $185-300$ & 290 & & 20.3 & \\
\hline & 3rd & $310-400$ & 334 & & 33.2 & \\
\hline & 4th & $410-600$ & 430 & & 6.2 & \\
\hline \multirow{3}{*}{ Treated } & $1 \mathrm{st}$ & 25-133 & 48 & \multirow{3}{*}{168} & 7.3 & \multirow{3}{*}{14.3} \\
\hline & 3rd & $190-380$ & 351 & & 71.4 & \\
\hline & 4th & $410-600$ & 420 & & 4.6 & \\
\hline \multirow{3}{*}{ Bleached } & $1 \mathrm{st}$ & $25-128$ & 48 & \multirow{3}{*}{160} & 6.5 & \multirow{3}{*}{18.4} \\
\hline & 3rd & 273-415 & 336 & & 60.3 & \\
\hline & 4th & $420-600$ & 423 & & 5.3 & \\
\hline
\end{tabular}

Table 1: TG/DTG data of untreated, treated and bleached Imperata brasiliensis fibers.

\subsection{Scanning Electron Microscopy (SEM)}


The morphology of fibers and the effect of treatments on the fibers surface was evaluated. The SEM micrographs of untreated fiber can be seen in Fig.4.

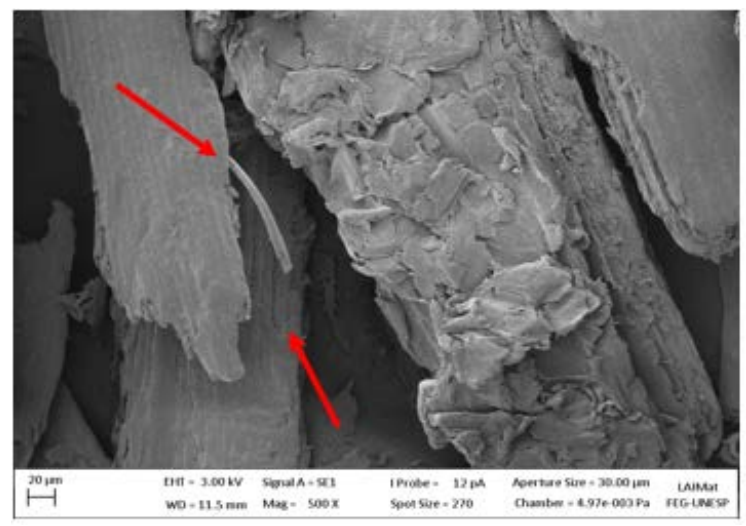

(a)

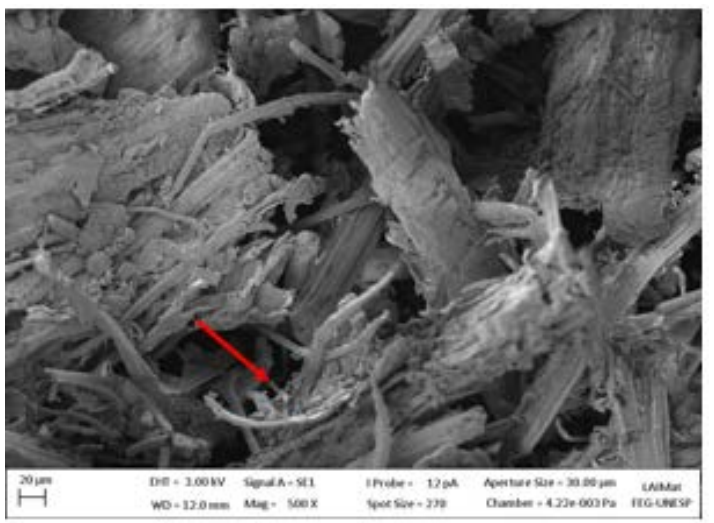

(b)

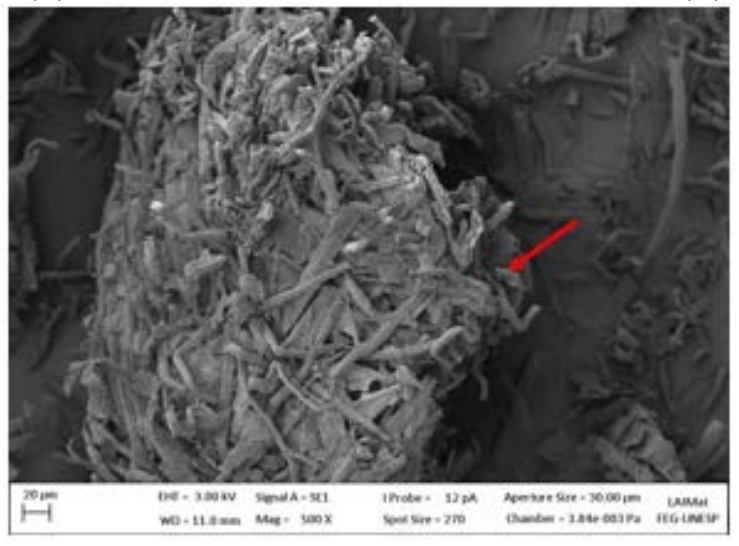

(c)

Fig. 4 SEM micrographs of (a) untreated fiber, (b) acetosolv fiber, and (c) bleached fiber.

Analyzing the micrographs of Fig. 4a, it is possible to observe that untreated fiber surface is covered by several layers of substances like pectin, lignin and other impurities [21]. In addition, microfibrils that join to form the fiber bundle can be observed. The micrographs of acetosolv fibers can be seen in Fig.4b and because of this treatment there is the formation of lignin oligomers that together with hemicellulose are solubilized in the solvent, remaining a portion of lignin, called residual [12]. These structural and surface modifications cause changes on the arrangement and the morphology of the fibers, which are defibrillated and therefore have a rougher surface, a good condition to reach a considerable adhesion between matrix and fibers in the composites $[18,20]$.

After bleaching the defibrillation process (as shown in Fig. 4c) is more pronounced and the surface presents a greater number of recesses in the ending of treatment which may improve mechanical properties of the fibers and its posterior composites [20]. These reentrances caused by defibrillation are important for subsequent application in the composites as it facilitates mechanical anchoring with the polymer matrix and make easier the bonding with hydroxyl groups of the matrix [21].

\section{CONCLUSIONS}


The effect of two chemical treatments, acetosolv pulping and bleaching, on thermal properties and surface aspect of Imperata brasiliensis grass have been studied. It was demonstrated, according to thermogravimetric analyses, the improvement on thermal stability of the fibers. Nevertheless, the removing of non-crystalline constituents of fibers was also observed by the color after each treatment, which corroborated to degradation peak present in DTG curves.

One can also observe the surface modification after each treatment. Acetosolv and mostly bleached fibers presented a considerable defibrillation. Additionally, several reentrances were observed, a physical characteristic that improve the subsequent adhesion between fiber and polymeric matrix of composites.

\section{ACKNOWLEDGMENTS}

The authors acknowledge FAPESP (2017/15461-4) for fellowships and financial support.

\section{REFERENCES}

[1] PANDEY, P. et al. Performance of UV weathered HDPE composites containing hull fiber from DDGS and corn grain. Industrial Crops \& Products. p. 1-11. jul. 2017.

[2] PICKERING, K.L.; EFENDY, M.G. A.; LE, T.M. A review of recent developments in natural fibre composites and their mechanical performance. Composites Part A: Applied Science And Manufacturing. S.i, p. 98-112. set. 2015.

[3] SANJAY, M.r. et al. Characterization and Properties of Natural Fiber Polymer Composites: A Comprehensive Review. Journal Of Cleaner Production. 09 out. 2017.

[4] NAIDU, D. S.; HLANGOTHI, S. P.; JOHN, M. J. Bio-based products from xylan: A review. Carbohydrate Polymers, [s.l.], v. 179, p.28-41, jan. 2018. Elsevier BV.

[5] STEFFENS, F.; STEFFENS, H.; OLIVEIRA, F. R. Applications Of Natural Fibers On Architecture. In: 3RD INTERNATIONAL CONFERENCE ON NATURAL FIBERS: ADVANCED MATERIALS FOR A GREENER WORLD, ICNF, 2017, Braga, Portugal. Peer-review. Braga, 2017. v. 200, p. 317 - 324.

[6] MOIGNE, N. Le et al. Study of the interface in natural fibres reinforced poly(lactic acid) biocomposites modified by optimized organosilane treatments. Industrial Crops And Products, [s.l.], v. 52, p.481-494, jan. 2014. Elsevier BV.

[7] OGUNSILE, B. O.; OLADEJI, Temitope Gbemi. Utilization of banana stalk fiber as reinforcement in low density polyethylene composite. Matéria, RJ , v.21, n.4, p. 953-963, Dez. 2016 .

[8] SILVA, R.; et al. Aplicações de fibras lignocelulósicas na química de polímeros e compósitos. Química Nova, v.32, p.661-67, 2009.

[9] POLETTO, M. et al. Thermal decomposition of wood: Influence of wood components and cellulose crystallite size. Bioresource Technology, [s.l.], v. 109, p.148-153, abr. 2012.

[10] KABIR, M.M. et al. Chemical treatments on plant-based natural fibre reinforced polymer composites: An overview. Composites Part B: Engineering. Australia, p. 2883-2892. Fev. 2012.

[11] FARUK, O. et al. Progress Report on Natural Fiber Reinforced Composites. Macromolecular Materials And Engineering. Kassel, p. 9-26. jan. 2014.

[12] HERNÁNDEZ-HERNÁNDEZ, H.M., et al. Acetosolv treatment of fibers from waste agave leaves: Influence of process variables and microstructural study. Industrial Crops and Products, v.86, p.163-172, 2016.

[13] BASAK, R.; CHOUDHURY, P.l.; PANDEY, K.M. Effect of Temperature Variation on Surface Treatment of Short Jute Fiber-Reinforced Epoxy Composites. Materials Today: Proceedings, [s.l.], v. 5, n. 1, p.1271-1277, 2018.

[14] AMERICAN SOCIETY FOR TESTING AND MATERIALS. ASTM E2550: Standard test method for thermal stability by thermogravimetry. United States, 2007. 
[15] SALAPA, I.; TOPAKAS, E.; SIDIRAS, D.; Simulation and optimization of barley straw organosolv pretreatment. Industrial Crops And Products, [s.l.], v. 113, p.80-88, mar. 2018.

[16] GILLGREN, T.; HEDENSTRÖM, M.; JÖNSSON, L. J. Comparison of laccase-catalyzed crosslinking of organosolv lignin and lignosulfonates. International Journal Of Biological Macromolecules, [s.l.], v. 105, p.438-446, dez. 2017. Elsevier BV.

[17] FAVERO, C. et al. ASPECTOS GERAIS DO PROCESSO DE PRÉ-BRANQUEAMENTO DE CELULOSE. EnciclopÉdia Biosfera, Goiania, v. 10, n. 18, p.3696-3710, jul. 2014

[18] MARTIN, A. R. et al. Studies on the thermal properties of sisal fiber and its constituents. Thermochimica Acta, São Carlos, v. 506, p.14- 19, 25 jul. 2017.

[19] ROSA, I. M. de et al. Morphological, thermal and mechanical characterization of okra (Abelmoschus esculentus) fibres as potential reinforcement in polymer composites. Composites Science And Technology, [s.l.], v. 70, n. 1, p.116-122, jan. 2010. Elsevier

[20] BENINI, K. C. C. C. Compósitos de nanocelulose/PHBV: manta microfibrílica por eletrofiação. 2015. 166 f. Tese (Doutorado em Engenharia Mecânica) - Universidade Estadual Paulista. Faculdade de Engenharia de Guaratinguetá, 2015.

[21] KARGARZADEH, H. et al. Effects of hydrolysis conditions on the morphology, cristallinity, and thermal stability of cellulose nanocrystals extracted from kenaf bast fibers. Cellulose, impress, 2012. 